\title{
James Watson to head NIH human genome project
}

\section{- Congress wants independent advisory body - International coordinating group set up}

Washington

THE National Institutes of Health (NIH) will announce later this month that James Watson, the director of the Cold Spring Harbor Laboratory, will become associate director of NIH. Watson will head a newly established office that will coordinate NIH efforts to map and sequence complex genomes.

The genome office, part of the office of the director, will not distribute research grants, but will instead provide general policy direction, identify neglected

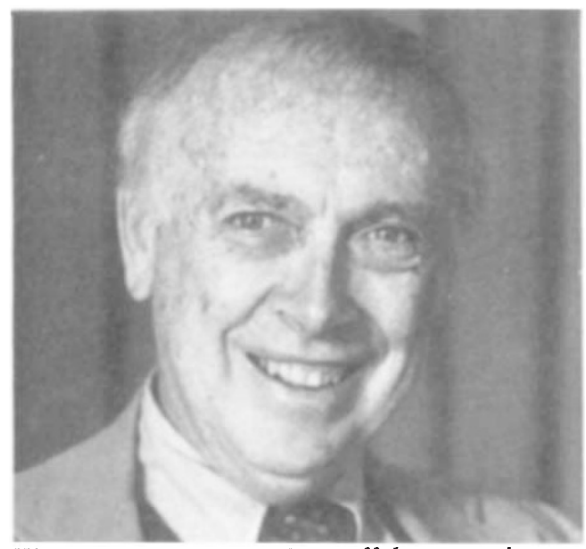

Watson - gets new projects off the ground.

research topics and target new technology. Watson has said that he also intends to encourage active investigations into the ethical issues raised by a genetic map of the human genome. Decisions about research grants will continue to fall to the National Institute of General Medical Science, which has a budget this year of just under the $\$ 28$ million in the Reagan administration's 1989 budget request.

Apart from his stature in the scientific community, Watson was thought the ideal choice for the job because of his ability to get new scientific projects off the ground. $\mathrm{He}$ is also popular with Congress which will ultimately have to pay for genome activities. Some wonder if, by making the transition from trusted outside adviser to a member of the federal bureaucracy, his relationship with Congress will change for the worse.

The decision to create a new associate director's position is a direct consequence of a meeting held last March at the behest of NIH director James Wyngaarden (see Nature 332, 99; 1988). Watson has been holding discussions with NIH since last spring over the possibility of taking the new position. He is expected to average only one day a week at Bethesda.

Although the NIH genome office has not yet officially opened for business, NIH has been moving on the project. It is in the process of concluding a memorandum of understanding with the Department of Energy (DoE) over genome activities. The memorandum would formalize existing informal relationships, and would establish an interagency working group to identify areas for joint activities.

The extremely cordial relations between the two agencies is in part explained by their desire to forestall legislation now pending in Congress that would establish an independent panel to advise on genome activities. The legislation, originated by Senator Lawton Chiles (Democrat, Florida) and passed by the Senate, calls for a national advisory panel on the human genome consisting of the Secretary of Energy, the directors of NIH, the National Science Foundation and the National Library of Medicine as well as four representatives from private industry, four academic researchers, one bioethicist and one representative from charitable foundations. Although both NIH and DoE acknowledge the need for an outside advisory panel, both would apparently prefer to establish their own advisory mechanism.

The Chiles bill is now awaiting action in the House of Representatives. In addition to establishing a genome advisory panel, it also establishes panels for biotechnology and agricultural biotechnology. Three different committees were given jurisdiction to hold hearings on the bill. One, the Science Space and Technology Committee, has completed its work, and the Agriculture Committee is expected to finish this week. That leaves the powerful Committee on Energy and Commerce chaired by Representative John Dingell (Democrat, Michigan), which has yet to schedule action on the bill.

As the domestic debate over who should provide guidance for the genome project continues, an international group is forming to add its voice to the chorus. HUGO, the Human Genome Organization, is an extra-governmental group that met last week in Lausanne, Switzerland, to discuss coordination of international efforts on the project. The meeting, paid for by the Howard Hughes Medical Institute, had representatives from Europe, the United States, the Soviet Union and Japan. The group has established an executive committee that will be headed by Lennart Philipson, the director of the European Molecular Biology Laboratory.
Uranium restrictions accepted by India Bangalore

THE Indian government seems willing to accept stringent conditions for the supply of enriched uranium by the Soviet Union, despite opposition within its own Department of Atomic Energy.

According to M.R. Srinivasan, chairman of the Atomic Energy Commission, a draft agreement for the supply of two Soviet $1,000-\mathrm{MW}$ pressurized light-water reactors is now under consideration. The terms already agreed by India include Soviet supply of enriched uranium for the power plants and the return to the Soviet Union of all used fuel rods.

India refused to return US-supplied fuel rods used in the Tarapur nuclear power plant to the United States on the grounds that India had paid for the fuel. The United States would not accept this position because of fears that plutonium could be extracted from the rods and used to make nuclear weapons.

Within the department, agreeing to similar Soviet regulations is seen as a blow to India's stand. Protests are likely to follow which will also draw attention to the poor safety record and lack of diagnostic systems in Soviet nuclear systems.

Radhakrishna Rao

\section{Britain wasting time}

\section{London}

HIGH-LEVEL radioactive waste should be buried in deep repositories underground without further delay. That is one of the main conclusions of a report published last week by the House of Lords Select Committee on the European Communities. "No better solution is discernible and it is irresponsible to wait any longer for some hopedfor but unspecified alternative." To allay public fears, these repositories should be monitored over a period but must eventually be permanently sealed, says the committee. In Britain, high- and intermediatelevel waste is at present stored where it is produced, pending a decision on disposal.

The committee is also satisfied that lowlevel waste can be satisfactorily disposed of in shallow repositories. All categories of waste can be suitably and permanently disposed of and decisions to do so should not be deferred to future generations, it says.

Christine McGourty

It has also established a finance committee that will look for funds to keep the group going. The Hughes Institute provided only enough to get the group started, and it has made no decision about future funding commitments.

Victor McKusick of Johns Hopkins University in Baltimore chaired the HUGO meeting. Joseph Palca 